\title{
Factors Affecting Sustainability Reporting Disclosure
}

\section{Galuh Artika Febriyanti ${ }^{1}$ Accounting Study Programme Ubaya Polytechnic, Indonesia}

Surel: galuh.af@staff.ubaya.ac.id

\section{ABSTRACT}

The aim is to determine the factors affecting sustainability reporting with a focus on firm age, woman presence, profitability, and leverage. The population in this study are manufacturing companies listed on the Indonesia Stock Exchange in 2018-2020. Total population consist of 103 firm-years that consistently publish sustainability reporting for the period 2018-2020. samples consist of 33 firm-years based on the criteria.Testing the data using multiple linear regression, the results showed that firm size, woman presence on board of commissioners', and profitability do not have a significant effect on the sustainability reporting disclosure. However, woman presence on board of directors and leverage had a significant effect on the sustainability reporting disclosure.

Keywords: Firm Size; Woman Presence On Board Of Commissioners; Woman Presence On Board Of Directors; Profitability; Leverage.

\section{Faktor-Faktor yang Mempengaruhi Pengungkapan Pelaporan Keberlanjutan}

\section{ABSTRAK}

Tujuan penelitian ini adalah untuk mengetahui faktor-faktor yang mempengaruhi pengungkapan sustainability reporting dengan fokus pada umur perusahaan, keberadaan wanita, profitabilitas dan leverage. Total populasi terdiri dari 103 perusahan yang menerbitkan sustainability reporting selama tahun 2018-2020. sampel terdiri dari33 perusahaan yang memenuhi kriteria. Obyek dari penelitian ini adalah perusahaan manufaktur yang listing di Bursa Efek Indonesia (BEI). Pengujian dalam penelitian ini menggunakan regresi linier berganda. Hasil penelitian menunjukkan ukuran perusahaan, keberadaan wanita pada dewan komisaris, dan profitabilitas tidak mempunyai pengaruh signifikan terhadap pengungkapan sustainability reporting. Penelitian ini menunjukkan keberadaan wanita pada dewan direksi dan leverage mempunyai pengaruh signifikan terhadap pengungkapan sustainability reporting.

Kata kunci: $\quad$ Ukuran Perusahaan; Keberadaan Wanita Pada Dewan Komisaris; Keberadaan Wanita Pada Dewan Direksi; Profitabilitas; Leverage.

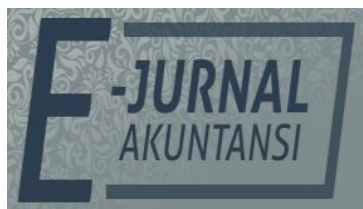

e-ISSN 2302-8556

Vol. 31 No. 12

Denpasar, Desember 2021

Hal. 3195-3206

DOI

10.24843/EJA.2021.v31.i12.p12

PENGUTIPAN:

Febriyanti, G. A. (2021).

Factors Affecting

Sustainability Reporting

Disclosure. E-Jurnal Akuntansi, 31(12), 3195-3206

RIWAYAT ARTIKEL:

Artikel Masuk: 16 September 2021 Artikel Diterima: 20 Desember 2021

Artikel dapat diakses: https://ojs.unud.ac.id/index.php/Akuntansi/index 


\section{INTRODUCTION}

The challenges faced by companies in advancing sustainable development have become a major topic worldwide. Companies need to consider sustainability not only in terms of economic, but also social and environmental aspects. One of the things carried out by companies in Indonesia to participate in achieving sustainable development is through sustainability reporting. This allows companies to report from both economic and non-economic perspectives. It also helps to measure and communicate the resulting impact of economic, social, and environmental performance from a government perspective. Furthermore, building and maintaining trust for the company is of fundamental importance. This trust is built from business strategies and choices which have an impact not only on the company but also on stakeholders. Another value contained in sustainability reporting is that the company considers all existing aspects and becomes more transparent. This is because it dares to show the problems, impacts, and risks faced to the public. Companies often ignore social and environmental impacts arising from the company's economic activities, eventhough the company's operations have the potential to cause damage to the surrounding environment (Vitriani \& Budiasih, 2019.).

Currently, stakeholder awareness and media pressure have driven companies to integrate sustainability into their vision, mission, strategy, planning, and decisions. As part of top management, the board of directors has a responsibility to ensure the protection of stakeholder interests by reading the company's sustainability disclosures (Zahid et al., 2020). In other words, sustainability reporting constitutes one of themain sources for managers to convey and disseminate information on sustainability activities to all stakeholders. According signalling theory, the higher the growth experienced by a company, the more positive value it will emit to investors (Budiana \& Budiasih, 2020). In Indonesia, the publication of sustainability reporting has become a trend, partly driven by the annual award initiated by the National Center for Sustainability Reporting (NCSR). Furthermore, to reduce the possibility of management misinterpretation and improve the quality of sustainability reporting, international standard-setters such as the Global Reporting Initiative (GRI) have developed materiality assessment guidelines to identify material matters that should be included.

Researches have been previously conducted to empirically examine the factors affecting the materiality of sustainability reporting disclosure. Firm size is a factor that significantly influences the sustainability reporting disclosure (Dissanayake et al., 2019; Sulistyawati \& Qadriatin, 2019). However, contrary results were observed by Natalia \& Wahidahwati (2016) which showed empirical evidence that firm size does not have a significant effect on the disclosure level. The company's profitability is also suspected to affect the sustainability reporting disclosure. Furthermore, companies with high profits increase their activities in sustainability reporting, while those that experience declining profits will reduce their activities (Setiawan et al., 2019). This disagreed with the research by Sulistyawati and Qadriatin (2019) as well as Natalia and Wahidahwati (2016). The presence of women on the board of commissioners and directors in a company is one of the most frequently studied measures of diversity (Pajaria et al., 2016). This 
is because the involvement of women in social and economic activities has become quite an interesting topic recently. They have equal opportunities in occupying all levels in the company from the lowest to the highest. Women are considered to be more careful in making decisions, avoid risk, as well as care about environmental and social conditions than men. Therefore, it is concluded that more sustainable activities will be carried out by the company if women become the board of directors. The existence of female commissioners is proven to have a significant effect on the disclosure of sustainable development goals (Farida, 2019). Contrary results were proven by (M. Shamil et al., 2014) that female commissioners have a negative relationship with the sustainability reporting disclosure. Furthermore, fulfillment of fund sources through debt (loans) will affect the company's leverage level, as leverage is a ratio used to measure how far the company incurs debt (Sutama \& Lisa, 2018). Leverage is considered to have a significant positive impact on the sustainability reporting disclosure. Companies with a high level of leverage attempt to disclose more information that is not only financial but also nonfinancial. Through sustainability reporting, the company reduces agency and supervision costs. Creditors also obtain a lot of information that is voluntarily disclosed by companies with high levels of leverage. This research aimed to empirically examine the factors affecting the sustainability reporting disclosure in manufacturing companies listed on the Indonesia Stock Exchange in 2018-2020.

Firm size may affect the extent of company information disclosure. According to the legitimacy theory, large companies are more visible and subject to greater public scrutiny and social pressure, large company have a huge environmental and social impact to their business operation (Usman, 2020).In general, large companies will disclose more information than small ones. Large companies with high profits are certainly able to incur more costs for the widest possible disclosure of financial statements or sustainability reporting. Furthermore, large companies tend to maintain a positive assessment from the community. They consider it necessary to carry out activities that are not only centered on making profits but also being responsible to stakeholders by carrying out activities, as contained in sustainability reporting. While small companies tend to be more concerned with profit oriented activities so they might not have been able to handle the social and environment issues (Manchiraju \& Rajgopal, 2017). Research on companies listed in Kazakhstan produced empirical evidence that the firm size variable significantly affects the sustainability reporting disclosure (Orazalin \& Mahmood, 2019). Dilling (2010) observed contrary results, where sales growth was used as a proxy for firm size, which shows a negative relationship with sustainability reporting. Companies with long-term growth tend not to provide high-quality sustainability reporting. This agrees with Natalia \& Wahidahwati (2016) which utilized a total asset proxy as the firm size. Furthermore, the total assets owned by the company do not affect the company's disclosure ability. Based on the aforementioned research gap, this research reexamines the effect of firm size on sustainability reporting disclosure, and the hypothesis.

$\mathrm{H}_{1}$ : Firm size has a significant effect on sustainability reporting disclosure.

The presence of women in the leadership of the company will result in a balanced decision. Women are considered to be more sensitive to sustainability 
issues, more generous, and considerate of the interests of employees and society (Bakar et al., 2019). The relationship between female board of directors and disclosure is based on this agency theory (Farida, 2019). In theory, the presence of a female board of directors will increase the independence of the board directors so that it will reduce agency costs and as a consequence there will be an increase in the value of company. In addition, the female board of directors has a high responsibility in the decision-making process decision. Women tend to be more altruistic and considerate when making decisions related to moral values (Ayu Indriyani \& Sudaryati, 2020). In a broad sense, feminism is a women's movement to reject everything that is marginalized, subordinated, and demeaned by the dominant culture in politics and economics as well as social life in general (Pajaria et al., 2016). Currently, many women have occupied leadership positions in companies.

Previous studies have examined women on boards from various perspectives. An empirical study found that woman presence on board of directors did not affect the disclosure of sustainability development goals, whereas woman presence on board of commissioners has a significant effect on the disclosure of sustainability development goals (Farida, 2019). This is because the role of woman presence on board of directors is only complement to show stakeholders that the company cares about equality gender. Modiba \& Ngwakwe (2017) found significant effect between the number of woman on the board of directors and sustainability disclosure. Based on the description above, the proposed hypotheses are.

$\mathrm{H}_{2}$ : Woman presence on board of commissioners has a significant effect on the sustainability reporting disclosure.

Chebbi et al (2020) found that the women presence on board and higher percentage of women on board lead to a higher level of firm environmental, social and governance disclosures. Thus, a higher board gender diversity results in a higher level of sustainability. Contrary results were observed by (Br Bangun \& Ridaryanto, 2021) that in the board of directors, gender diversity does not affect on the sustainability reporting disclosure. Based on the description above, the proposed hypotheses are.

$\mathrm{H}_{3}$ : Woman presence on board of directors has a significant effect on the sustainability reporting disclosure.

Profitability is a measure in determining the amount of profit from the company's performance which will affect the financial statement records in accordance with existing standards (Wagiswari \& Badera, 2021). Companies with high profitability will tend to make disclosures through sustainability reporting because profitability is one of the performance indicators that must be disclosed in sustainability reporting. Disclosure of sustainability reporting is carried out by the company as a form of accountability to stakeholders so that they continue to provide support.

(Mujiani \& Jayanti, 2020) examined the effect of profitability on sustainability reporting on ISRA participating companies in Indonesia. The results showed that profitability has a significant effect on the sustainability reporting disclosure. This was because companies with high profitability attempt to gain legitimacy from stakeholders through sustainability reporting disclosure. 
Contrary results on the effect of profitability on sustainability reporting disclosure stated that companies want to portray the image that they care about sustainability when the profits are large or small. Furthermore, one of the reasons companies implement social and environmental responsibilities is due to demands from stakeholders, including activists and the general public. In other words, profitability does not effect on the sustainability reporting disclosure (Maulida\& Adam, 2012), (Natalia \& Wahidahwati, 2016).

Therefore, the fourth hypothesis proposed in this research is:

$\mathrm{H}_{4}$ : Profitability has a Significant Possitive Effect on The Sustainability Reporting

Disclosure.

Leverage is described as the amount of debt owed by the company that is used to acquire assets. Companies with a high level of leverage are considered to provide more voluntary information to creditors. This increases creditor confidence to provide loans to companies. The leverage ratio measures how much of the company is financed with debt (Damayanti \& Hardiningsih, 2021). Leverage has a significant negative effect on the company's sustainability reporting disclosure. The higher the leverage, the more likely the company will experience a violation of debt contracts, and managers will try to report higher current profits than future profits. For reported profits to be high, managers should reduce costs including disclosing sustainability performance information (Maulida\& Adam, 2012). In contrast to some of these research, leverage is not a factor that affects the sustainability reporting disclosure. This is supported by research which states that leverage has a negative relationship and no effect on the sustainability reporting disclosure (Orazalin \& Mahmood, 2019), (Wicaksono \& Septiani, 2020). Sustainability reporting voluntarily disclosed by the company is considered one of the reports that increases creditors' trust in the company. Thehigher thecompany's leverage, the more sustainability reporting disclosures are made voluntarily, thereby reducing information asymmetry. Therefore, the hypothesis proposed in this research.

$\mathrm{H}_{5}$ : Leverage has a Significant Effect on Sustainability Reporting Disclosure.

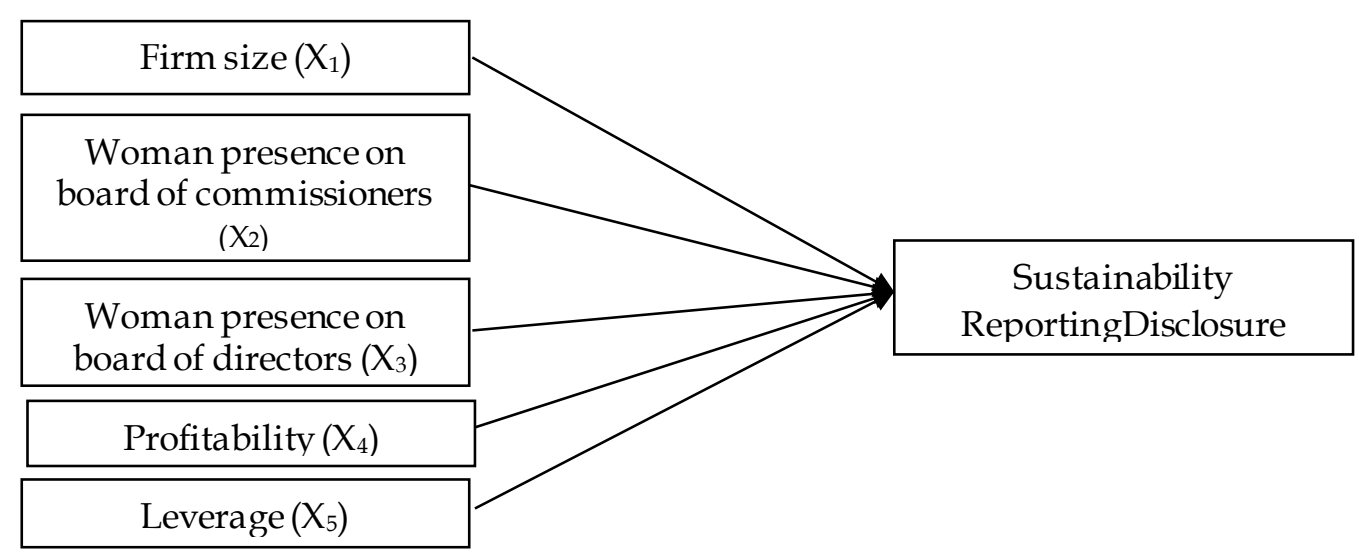

Source: Processed data, 2021

Figure 1. Research Model 


\section{RESEARCH METHOD}

This quantitative research utilized the object of annual reports and sustainability reporting which are published separately from financial statements. Thepopulation in this study were all manufacturing company listed on Indonesia Stock Exchange in the period 2018-2020. The sampling technique used purpose sampling technique. The population in this study are manufacturing companies listed on the Indonesia Stock Exchange in 2018-2020. Total population consist of 103 firm-years that consistently publish sustainability reporting for the period 2018-2020. samples consist of 33 firm-years based on the criteria.

The sustainability reporting variable was measured by the Sustainability Report Disclosure Index (SRDI) based on the Global Initiative Reporting (GRI) Standard. The SRDI calculation was carried out by giving a score of 1 if an item is disclosed, and 0 if it is not disclosed. After scoring all the items, the scores were then summed to get a total score for each company. The formula for calculating the SDI based on Kuswanto (2019).

Description:

$$
\text { SRDI }=\frac{\mathrm{n}}{\mathrm{k}}
$$

SRDI = Company's Sustainability Report Disclosure Index

$\mathrm{n} \quad=$ the number of items disclosed by the company

$\mathrm{k}=\quad$ Expected number of items

In this research, firm size was measured by looking at the total assets that were proxied through the logarithm of the company's total assets (Orazalin \& Mahmood, 2019). This was performed to determine the difference between large and small companies.

$$
\text { Size }=\text { Total asset } \log
$$

The presence of women on the board of commissioners is assessed using a dummy variable, 1 if the company has a female board of commissioners and 0 if not (Abdullah \& Ismail, 2013). Profitability in this study uses ROA to show the company's management ability to earn revenue through managing its assets to generate profits.

$$
\text { Profitability }=\frac{\text { Netprofit }}{\text { Totalassets }}
$$

The leverage ratio in this research uses the debt to asset ratio (DAR).

$$
\mathrm{DAR}=\frac{\text { Total debt }}{\text { Total assets }}
$$

Testing the data using multiple linear regression with SPSS software.The regression equation model is as follow.

$$
\mathrm{SR}=\alpha+\beta 1 \text { Size }+\beta 2 \mathrm{KOMUT}+\beta 3 \mathrm{DIR}+\beta 4 \mathrm{PROFIT}+\beta 5 \mathrm{DAR}+\varepsilon
$$

Description :

$$
\begin{aligned}
& \text { SR = Sustainability Reporting Disclosure } \\
& \text { a } \quad=\text { Constant } \\
& \beta 1-\beta 3=\text { Regression Coefficients } \\
& \text { Size } \quad=\text { Firm Size } \\
& \text { KOMUT = Woman Presence On Board Of Commissioners } \\
& \text { DIR = Woman Presence On Board Of Directors } \\
& \text { PROFIT = Profitability } \\
& \text { DAR = Debt To Total Asset Ratio (Leverage) } \\
& \varepsilon \quad=\text { Error }
\end{aligned}
$$




\section{RESULT AND DISCUSSION}

Descriptive statistics were carried out on the variables used in this research. These consist of sustainability reporting variables, firm size (SIZE), woman presence on board of commissioners (KOMUT), woman presence on board of directors (DIR), profitability (PROFIT), and leverage (DAR). The following is a tabular description of the statistical analysis of the research variables:

Table 1. Descriptive Statatistics

\begin{tabular}{llllll}
\hline & $\mathrm{N}$ & Min & Max & Mean & Std. Dev \\
\hline SR & 33 & 0.13 & 0.60 & 0.268 & 0.111 \\
SIZE & 33 & 12.37 & 14.55 & 13.319 & 0.562 \\
KOMUT & 33 & 0.00 & 1.00 & 0.545 & 0.505 \\
DIR & 33 & 0.00 & 1.00 & 0.454 & 0.505 \\
PROFIT & 33 & 0.01 & 0.45 & 0.111 & 0.105 \\
DAR & 33 & 0.13 & 0.76 & 0.427 & 0.202 \\
Valid N (listwise) 33 & & & &
\end{tabular}

Valid N (listwise) 33

Table 1 shows the sustainability reporting disclosure variable has a minimum value of 0.13 , a maximum value of 0.60 . an average value of 0.268 and a standard deviation value of 0.11158 . The firm size variable has a minimum value of 12.37, a maximum value of 14.55, an average value of 13.319 and a standard deviation value of 0.562 . The board of commissioners gender diversity variable has a minimum value of 0.00 . a maximum value of 1 , an average value of 0.545 and a standard deviation value of 0.505 . The board of directors gender diversity variable has a minimum value of 0.00 . a maximum value of 1 , an average value of 0.454 and a standard deviation value of 0.505 . The profitability variable has a minimum value of 0.01 , a maximum value of 0.45 , an average value of 0.111 and a standard deviation value of 0.105 . The leverage variable has a minimum value of 0.13 , a maximum value of 0.76 , an average value of 0.427 and a standard deviation value of 0.202 . The value of the standard deviation of woman presence on board of directors variable have a value above the average, which means that the data used in the sustainability reporting variable have a relatively larger and less distributed. While the other variables has a value below the average which means that the data used in the sustainability reporting variables has a smaller and more even distribution.

Classical assumption tests consisting of normality, multicollinearity, heteroscedasticity, and autocorrelation testswerecarried out before testing the hypothesis. All variables met the requirements of the classical assumption test.

The first hypothesis of this research states that the firm size has a significant effect on the sustainability reporting disclosure. From Table 2, the significance value of firm size (SIZE) was 0.978 , with a level of $=5 \%$, and the regression coefficient has no significant effect. Therefore, hypothesis 1 is rejected. The research results do not support the hypothesis that the firm size has a significant effect on the sustainability reporting disclosure which is proxied by the logarithm of total assets. These results are in accordance with research conducted by Dilling (Dilling, 2010) and Natalia and Wahidahwati (Natalia \& Wahidahwati, 2016). This shows that companies with large assets do not automatically disclose more sustainability 
FEBRIYANTI, G. A. FACTORS AFFECTING SUSTAINABILITY...

Table 2. Partial Significance Test Results (t-test)

\begin{tabular}{llccccc}
\hline \multirow{2}{*}{ Model } & \multicolumn{2}{c}{ Unstandardized Coef } & Standardized Coef & \multirow{2}{*}{$\mathrm{t}$} & \multirow{2}{*}{ Sig. } \\
\cline { 2 - 5 } & B & Std. Error & Beta & & \\
\hline 1 & (Const) & 0.209 & 0.524 & & 0.399 & 0.693 \\
& SIZE & -0.001 & 0.040 & -0.006 & -0.028 & 0.978 \\
& KOMUT & -0.026 & 0.047 & -0.116 & -0.540 & 0.594 \\
& DIR & -0.079 & 0.042 & -0.360 & $-1,902$ & 0.068 \\
& PROFIT & -0.071 & 0.172 & -0.069 & -0.412 & 0.684 \\
& DAR & 0.308 & 0.107 & 0.560 & 2.867 & 0.008 \\
\hline
\end{tabular}

Source: Processed data, 2021

Reporting than companies with small assets. Sustainability reporting that was still voluntary in Indonesia is viewed by companies as something that does not need to be disclosed. The company still considers that it is sufficient to carry out non-financial activities through Corporate Social Responsibility (CSR) activities without the need for sustainability reporting.

The second hypothesis of this research states that the woman presence on board of commissioners has a significant effect on the sustainability reporting disclosure. From Table 2, the significance value of the woman presence on board of commissioners (KOMUT) is 0.594 , with a level of $=5 \%$. The regression coefficient had no significant effect, therefore, hypothesis 2 is rejected. The research results do not support the hypothesis that woman presence on board of commissioners has a significant effect on the sustainability reporting disclosure. This is not in accordance with the research conducted by Farida (Farida, 2019) but agrees with Pajaria et al (Pajaria et al., 2016). The female presence on the board of commissioners does not indicate that companies will disclose more activities in sustainability reporting. This may happen because the proportion of the number of female commissioners is still small. Therefore, they cannot play a dominant role in decision-making, especially those related to non-financial activities as required in sustainability reporting. The number of female commissioners in the companies sampled in this research was only around 1-2 people, while the rest were male.

The third hypothesis in this research states that the woman presence on board of directors has a significant effect on the sustainability reporting disclosure. Table 2 shows the significance value of the woman presence on board of directors (DIR) was 0.068 , with a level of $=5 \%$. The regression coefficient had no significant effect. Meanwhile, with a significance level of $10 \%$, the regression coefficient has a significant effect, therefore, hypothesis 3 is accepted. The research results proved that woman presence on board of directors had a significant effect on the sustainability reporting disclosure. Females on the board of directors play an important role in the development of corporate sustainability disclosure (Zahid et al., 2020). The female presence encourages companies to provide disclosures in sustainability reporting. In accordance with the theory of feminist ethical theory that when faced with moral choices, females have higher and altruistic concerns. Females also have a high concern for individuals and the lives of others when making decisions (Ayu Indriyani \& Sudaryati, 2020).

The fourth hypothesis in this research states that profitability has a significant effect on the sustainability reporting disclosure. Table 2 shows a significance value of profitability (PROFIT) 0.684 , with a level of $=5 \%$, the 
regression coefficient has no significant effect, therefore hypothesis 4 is rejected. The research results do not support the hypothesis that profitability has a significant effect on the sustainability reporting disclosure. Companies that have high profits will not always disclose wider sustainability reporting than companies with low profits. This result agrees with (Damayanti \& Hardiningsih, 2021; Setiawan et al., 2019) which showed empirical evidence that profitability does not significantly influence the sustainability reporting disclosure because the company is still focused on pursuing profit. Therefore, it is not focused on non-financial activities. The tendency of investors to look at financial performance is also the reason companies focus more on profits than activities in sustainability reporting. These results contradict previous research which showed a significant relationship between profitability and sustainability reporting (Mujiani \& Jayanti, 2021).

The fifth hypothesis in this research states that leverage has a significant effect on the sustainability reporting disclosure. Table 2 shows the significance value of leverage (LEV) of 0.008 , with a level of $=5 \%$. The regression coefficient has a significant effect, therefore, hypothesis 5 is accepted. The research results prove that leverage has a significant effect on the sustainability reporting disclosure. Companies that have high leverage provide as much information as possible, including information on sustainability reporting to creditors to show that the company's performance is very good. This also helps to prove that the company does not only focus on financial but also non-financial activities. By providing information voluntarily, it is hoped that creditors will increase their trust in the company. Agency theory also states that shareholders will reduce doubts about the company's performance if the company provides relevant and comprehensive information. Furthermore, agency theory also supports companies to increase voluntary disclosure to avoid potential pressure from regulatory agencies (Kuzey \& Uyar, 2017). These results do not agree with previous research (Orazalin \& Mahmood, 2019), (Wicaksono \& Septiani, 2020). The higher the leverage, the more likely the company will experience debt contract violations. Therefore, managers will try to report higher current earnings than future earnings. In order for reported earnings to be high, managers should reduce costs, including that of disclosing sustainability performance information (Maulida \& Adam, 2012).

\section{CONCLUSION}

Although sustainability reporting has not yet become a mandatory report in Indonesia, the number of companies reporting it is increasing. Empirical testing was carried out to determine which factors influence the sustainability reporting disclosure. From the results of multiple linear regression tests, the variables of woman presence on board of directors and leverage significantly influence the sustainability reporting disclosure, while that of firm size, the woman presence on board of commissioners, and profitability have no effect on the sustainability reporting disclosure.From the analysis, results and conclusions that the author has put forward above, the suggestions that the author can convey are this research only uses a sample of manufacturing companies listed on the Indonesia Stock Exchange in 2018-2020. Therefore, the number of samples is relatively small. 
Further research can utilize samples of other companies listed on the Indonesia Stock Exchange.The measurement of woman presence on board of commissioners and directors in this research uses a dummy variable. For example, if the company has a female board of commissioners or directors, a score of 1 and 0 is given to companies that do not have a female board of commissioners and directors. Further research may involve the measurement of the percentage of the number of female commissioners and directors.Further research could examines the effect of the economic, social, and environmental dimensions in measuring sustainability reportingdisclosure.

\section{REFERENCES}

Abdullah, S.N., \& Ismail, K.N.I.K. (2013). Gender, Ethnic, and Age Diversity of the Boards of Large Malaysian Firms and Performance. Jurnal Pengurusan, 38, 27-40. https:/ / ejournal.ukm.my/pengurusan/article/view/ 4609.

Ayu Indriyani, D., \& Sudaryati, E. (2020). Pengaruh Keragaman Gender Dewan, Industri dan Ukuran Perusahaan terhadap Donasi Corporate Social Responsibility. E-Jurnal Akuntansi, 30(8), 2009-2024. https:/ / doi.org/10.24843/EJA.2020.v30.i08.p09.

Bakar, A. B. S. A., Ghazali, N. A. B. Mohd., \& Ahmad, M. B. (2019). Sustainability Reporting and Board Diversity in Malaysia. International Journal of Academic Research in Business and Social Sciences, 9(2), 91-99. https: / / doi.org/10.6007/IJARBSS/v9-i2/5663.

Budiana, AQ., dan Budiasih (2020). Profitabilitas Sebagai Pemoderasi Pengaruh Pengungkapan Sustainability Reporting pada Nilai Perusahaan Pemenang Indonesian Sustainability Reporting Award. E-Jurnal Akuntansi, 30(3). https:// doi.org/10.24843/EJA.2020.v30.i03.p09.

Br Bangun \& Ridaryanto (2021). Pengaruh Diversitas Dewan Direksi terhadap Pengungkapan Sustainability Report dan Nilai Perusahaan (Studi pada Perusahaan Perbankan di Bursa Efek Indonesia Periode 2016-2018. Joumal of Management Studies, 6(1), http:/ /dx.doi.org/10.33021/firm.v6i1.1281.

Chebbi, K., Aliedan, M.M., \& Mohammed, A. (2020). Woman on the Board and Environmental Sustainability Reporting: Evidence from France. International Journal of Innovation, 14(11), 231-258. h https:/ / www.ijicc.net/images/Vol_14/Iss_11/141115_Chebbi_2020_E1_ R.pdf

Damayanti, A., \& Hardiningsih, P. (2021). Determinan Pengungkapan Laporan Berkelanjutan. Jurnal Akuntansi dan Pajak, 22(01), 1-16. http:/ / dx.doi.org/10.29040/jap.v22i1.2756.

Dilling, P. F. A. (2010). Sustainability Reporting In A Global Context: What Are The Characteristics Of Corporations That Provide High Quality Sustainability Reports An Empirical Analysis. International Business $\mathcal{E}$ Economics Research Journal (IBER), 9(1), 19-30. https:/ / doi.org/10.19030/iber.v9i1.505.

Dissanayake, D., Tilt, C., \& Qian, W. (2019). Factors InfluencingSustainabilityReporting by Sri Lankan Companies. Pacific Accounting Review, 31(1), 67-92. https:// doi.org/10.1108/PAR-10-20170085. 
Farida, D. N. (2019). Pengaruh Diversitas Gender Terhadap Pengungkapan Sustainability Development Goals. Jurnal Akuntansi Indonesia, 8(2), 89-107. https:/ / doi.org/10.30659/jai.8.2.89-107.

Kuswanto, R. (2019). Penerapan Standar GRI dalam Laporan Keberlanjutan di Indonesia: Sebuah Evaluasi. Jurnal Bina Akuntansi, 6(2), 1-21. https:/ / doi.org/10.52859/jba.v6i2.59.

Kuzey, C., \& Uyar, A. (2017). Determinants of Sustainability Reporting and Its Impact on Firm Value: Evidence From The Emerging Market of Turkey. Journal of Cleaner Production, 143, 27-39. https:/ / doi.org/10.1016/j.jclepro.2016.12.153.

Modiba, E. M., \& Ngwakwe, C. C. (2017). Women on the Corporate Board of Directors and Corporate Sustainability Disclosure. Corporate Board Role Duties and Composition, 13(2), 32-37. https://doi.org/10.22495/cbv13i2art3

M. Shamil, M., M. Shaikh, J., Ho, P.-L., \& Krishnan, A. (2014). The Influence of Board Characteristics on Sustainability Reporting: Empirical Evidence From Sri Lankan Firms. Asian Review of Accounting, 22(2), 78-97. https:/ / doi.org/10.1108/ARA-09-2013-0060.

Manchiraju, H., \& Rajgopal, S. (2017). Dose Corporate Social Responsibility (CSR) Create Shareholders Value? Evidencefrom the Indian Companies Act 2013. Journal of Accounting Research, 55(5), 1257-1300. https:/ / doi.org/10.1111/1475-679X.12174.

Maulida\& Adam, H. (2012). Faktor-Faktor Yang Mempengaruhi Pengungkapan Sustainability Performance (Studi pada website perusahaan manufaktur terdaftar di Bursa Efek Indonesia tahun 2011). Jurnal Ilmiah Mahasiswa FEB, 1(02), 1-25. https:/ /jimfeb.ub.ac.id/index.php/jimfeb/article/view/ 449.

Mujiani, S., \& Nurfitri (2020). Analisis Faktor-Faktor Yang Mempengaruhi Pengungkapan Sustainability Report Pada Perusahaan LQ45 Yang Terdaftar Di Bursa Efek Indonesia. Jurnal Akuntansi dan Keuangan, 2(1), 1835. https:/ / uia.e-journal.id/Akrual/article/view/1042.

Mujiani, S., \& Jayanti. (2021). Analisis Pengaruh Profitabilitasdan Good Corporate Governance Terhadap Sustainability Report Pada Perusahaan Peserta ISRA di Indonesia. Jurnal Ilmu Akuntansi, 19 (1). 21-44. http://journal.unas.ac.id/akunnas/article/view/1084.

Natalia, O., \& Wahidahwati. (2016). Faktor-Faktor Yang Mempengaruhi Tingkat Pengungkapan. Jurnal Ilmu dan Riset Akuntansi, 5(11), 1-23. http:/ /jurnalmahasiswa.stiesia.ac.id/index.php/jira/article/view/2465/ 2468.

Orazalin, N., \& Mahmood, M. (2019). Determinants of GRI-based sustainability reporting: Evidence from an emerging economy. Journal of Accounting in Emerging Economies, 10(1), 140-164. https://doi.org/10.1108/JAEE-122018-0137.

Pajaria, Y., Meutia, I., \&Widiyanti, M. (2016). PengaruhDiversitasDewanDireksi Dan Komisaris, Ukuran Perusahaan, Dan ProfitabilitasTerhadapPengungkapan Corporate Social Responsibility Perusahaan SektorManufaktur Yang Terdaftar Di Bursa Efek Indonesia.Akuntabilitas: Jurnal Penelitian dan Pengembangan Akuntansi,10(2), 177-200. https://doi.org/10.29259/ja.v10i2.8893. 
Setiawan, K., Mukhzarudfa, \& Hizazi, A. (2019). Pengaruh Profitabilitas, Solvabilitas, dan Ukuran Perusahaan Terhadap Pengungkapan Sustainability Report Pada Perusahaan Perbankan yang Terdaftar di Bursa Efek Indonesia dan Bursa Efek Malaysia Periode 2013-2017. Jurnal $\begin{array}{llll}\text { Akuntansi } \mathcal{E} \text { Keuangan Unja, 4(2), 30-40. } & \end{array}$ https:// doi.org/10.22437/jaku.v4i2.7794.

Sulistyawati, A. I., \& Qadriatin, A. (2019). Pengungkapan Sustainability Report Dan Faktor-Faktor Yang Mempengaruhinya. Majalah Ilmiah Solusi, 16(4), 122. https:/ / doi.org/10.26623/slsi.v16i4.1665.

Sutama, D. R., \& Lisa, E. (2018). Pengaruh Leverage dan ProfitabilitasTerhadapNilai Perusahaan (Studi pada Perusahaan Sektor Manufaktur Food and Beverage yang Terdaftar. Jurnal Sains Manajemen $\mathcal{E}$ Akuntansi, $\quad X(1)$, 21-39.http://ojs.stanim.ac.id/index.php/JSMA/article/view/26.

Usman, B. (2020). CSR Performance, Firm's Attributes, and Sustainability Reporting. International Journal of Business and Society, 21(2), 521-539. https:/ / doi.org/10.33736/ijbs.3269.2020.

Vitriani, Ni Putu Lisna., \& Budiasih. (2019). Pengaruh Kualitas Pelaporan Keuangan dan Sustainability Reporting Pada Efisiensi Investasi. E-Jumal Akuntansi, 28(1). https: / / doi.org/10.24843/ EJA.2019.v28.i01.p08.

Wagiswari, N.L.S \& Badera, I.D.N. (2021). Profitabilitas, Aktivitas Perusahaan, Tipe Industri dan Pengungkapan Sustainability Report. E-Journal Akuntansi, $\quad 31(9)$.

23122325.https:/ / doi.org/10.24843/EJA.2021.v31.i09.p13.

Wicaksono, R. R., \& Septiani, A. (2020). Determinan Sustainability Report Dan Pengaruh Terhadap Nilai Perusahaan. Diponegoro Journal of Accounting, 9(2), 15.(https://ejournal3.undip.ac.id/index.php/accounting/article/view/2 7590/24035).

Zahid, M., Rahman, H. U., Ali, W., Khan, M., Alharthi, M., Imran Qureshi, M., \& Jan, A. (2020). Boardroom Gender Diversity: Implications for Corporate Sustainability Disclosures in Malaysia. Journal of Cleaner Production, 244, 114. https:/ / doi.org/10.1016/j.jclepro.2019.118683. 